\title{
Revista Brasileira de Fruticultura \\ Physical, chemical, microbiological and sensory carachterization of Manipuça jellies for municipal school meals of Fortaleza-CE
}

\author{
Lidiane Medeiros Freitas Azevedo ${ }^{1}$, Eliseu Marlônio Pereira de Lucena ${ }^{2}$, \\ Oriel Herrera Bonilla ${ }^{3}$, Márcia Régia Souza da Silveira ${ }^{4}$, Antenor Silva Júnior ${ }^{5}$
}

Abstract - This research aimed to characterize the physical, chemical, microbiological and sensory characterization of manipuçá (Mouriri cearensis Huber) jellies as an alternative to school meals of an elementary public school in Fortaleza-CE. The fruits, in maturation stages 4 (mature) and 5 (senescent), were collected in the Botanical Garden of São Gonçalo, in São Gonçalo do Amarante-CE. Initially, the fruits of manipuça were processed and to obtain the jelly five formulations were proposed (treatments) containing different proportions of water and pulp $\left(4: 1-\mathrm{F}_{1} ; 4: 2-\mathrm{F}_{2}, 4: 3-\mathrm{F}_{3}: 4: 4-\mathrm{F}_{4}\right.$; and $\left.4: 5-\mathrm{F}_{5}\right)$, which then they were subjected to physicochemical analysis (total soluble solids-TSS; total titratable acidity-TTA; $\mathrm{pH}$; TSS/TTA ratio-SAR; vitamin C-CV; total soluble sugar-TSSu, reducing sugar-RS and non-reducing sugars-NRS), microbiological (coliforms at $35^{\circ} \mathrm{C}-\mathrm{CF}$ ) and sensory (aroma-A; color-C; appearance-AP; flavor-F; texture-T; and the purchaser intends-PI). We used the Assistat program in statistical analyzes. The results showed the following variation in the five formulations: TSS $\left({ }^{\circ} \mathrm{Brix}\right)-72\left(\mathrm{~F}_{1}\right)$ to $85.12\left(\mathrm{~F}_{5}\right)$; TTA (\%) - $0.95\left(\mathrm{~F}_{1}\right)$ to $0.54\left(\mathrm{~F}_{5}\right)$; $\mathrm{pH}-4.09\left(\mathrm{~F}_{1}\right)$ to $4.30\left(\mathrm{~F}_{5}\right)$; $\mathrm{SAR}-75.22\left(\mathrm{~F}_{1}\right)$ to $156.20\left(\mathrm{~F}_{5}\right)$; $\mathrm{CV}(\mathrm{mg}$ / 100g) - $7.40\left(\mathrm{~F}_{2}\right)$ to $14.19\left(\mathrm{~F}_{5}\right)$; TS $(\%)-63.97\left(\mathrm{~F}_{1}\right)$ to $79.73\left(\mathrm{~F}_{5}\right)$; RS $(\%)-44.53\left(\mathrm{~F}_{2}\right)$ to $66.98\left(\mathrm{~F}_{5}\right)$; NRS (\%) - $12.47\left(\mathrm{~F}_{1}\right)$ to $32.98\left(\mathrm{~F}_{4}\right)$; absence of $\mathrm{CF}$; for A, C, AP, F and T, $\mathrm{F}_{5}$ was greater than $\mathrm{F}_{2}, \mathrm{~F}_{3}$, $\mathrm{F}_{4}$ and equals to $\mathrm{F}_{1}$; and for PI, $\mathrm{F}_{5}$ was superior to all. In conclusion: the $\mathrm{F}_{5}$ is sweeter and less acidic, however, the $\mathrm{F}_{1}$ is less sweet and more acidic; the $\mathrm{F}_{5}$ obtained greater acceptance among students, so this is the ideal formulation to use as an alternative to school meals for primary school students from public schools in Fortaleza-CE.

Index terms: Mouriri cearensis, Restinga fruit, exploitation, processing, food technology.

\section{Caracterização física, química, microbiológica e sensorial de geleias de Manipuçá para a merenda escolar municipal de Fortaleza-CE}

\section{Corresponding author:}

E-mail: lidianemedeiros.bio@gmail.com

Received: October 27, 2016.

Accepted : June 22, 2017.

Copyright: All the contents of this journal, except where otherwise noted, is licensed under a Creative Commons Attribution License.

Resumo - A presente pesquisa objetivou fazer a caracterização física, química, microbiológica e sensorial de geleias de manipuçá (Mouriri cesrensis Huber) como uma alternativa para a merenda escolar do Ensino Fundamental das escolas públicas municipais de Fortaleza-CE. Os frutos, nos estádios 4 (maduro) e 5 (senescente) de maturação, foram colhidos no Jardim Botânico de São Gonçalo, em São Gonçalo do Amarante-CE. Inicialmente, os frutos do manipuçá foram processados e, para obtenção de geleia, foram

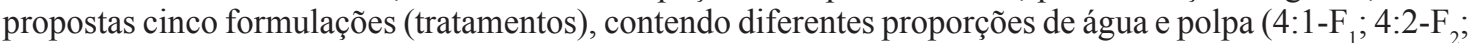
$4: 3-\mathrm{F}_{3} 4: 4-\mathrm{F}_{4} ;$ e $4: 5-\mathrm{F}_{5}$ ), que em seguida foram submetidas às análises físico-químicas (sólidos solúveis totaisSST; acidez total titulável-ATT; pH; relação SST/ATT-RSA; vitamina C-VC; açúcares solúveis totais-AST, redutores-AR e não redutores-ANR), microbiológica (coliformes a $35^{\circ} \mathrm{C}-\mathrm{CF}$ ) e sensoriais (aroma-A; cor-C; aparência-AP; sabor-S; textura-T; e intenção de compra-IC). Utilizou-se o programa Assistat nas análises estatísticas. Os resultados apresentaram a seguinte variação nas cinco formulações: SST $\left({ }^{\circ} \mathrm{Brix}\right)-72\left(\mathrm{~F}_{1}\right)$ a 85,12 $\left(\mathrm{F}_{5}\right)$; ATT $(\%)-0,95\left(\mathrm{~F}_{1}\right)$ a $0,54\left(\mathrm{~F}_{5}\right)$; pH - 4,09 $\left(\mathrm{F}_{1}\right)$ a 4,30 $\left(\mathrm{F}_{5}\right)$; RSA - 75,22 $\left(\mathrm{F}_{1}\right)$ a $156,20\left(\mathrm{~F}_{5}\right)$; $\operatorname{VC}(\mathrm{mg} / 100 \mathrm{~g})$ - 7,40 $\left(\mathrm{F}_{2}\right)$ a 14,19 $\left(\mathrm{F}_{5}\right)$; $\operatorname{AST}(\%)$ - 63,97 $\left(\mathrm{F}_{1}\right)$ a 79,73 $\left(\mathrm{F}_{5}\right) ; \operatorname{AR}(\%)-44,53\left(\mathrm{~F}_{2}\right)$ a $66,98\left(\mathrm{~F}_{5}\right)$; ANR $(\%)$ - 12,47 $\left(\mathrm{F}_{1}\right)$ a 32,98 $\left(\mathrm{F}_{4}\right)$; ausência de CF; para A, C, AP, S e T, a $\mathrm{F}_{5}$ foi superior a $\mathrm{F}_{2}, \mathrm{~F}_{3}, \mathrm{~F}_{4}$ e igual a $\mathrm{F}_{1}$; e para $\mathrm{IC} \mathrm{a}_{5}$ foi superior a todas. Conclui-se que: a $\mathrm{F}_{5}$ é a mais doce e menos ácida; entretanto, a $\mathrm{F}_{1}$ é a menos doce e mais ácida; $\mathrm{a} \mathrm{F}_{5}$ obteve maior aceitação entre os estudantes, portanto esta é a formulação ideal para ser utilizada como alternativa na merenda escolar dos alunos de Ensino Fundamental das escolas municipais de Fortaleza-CE.

Termos para indexação: Mouriri cearensis, fruta da Restinga, aproveitamento, processamento, tecnologia de alimentos.

\footnotetext{
${ }^{1}$ Master in Natural Resources, Universidade Estadual do Ceará. E-mail: lidianemedeiros.bio@gmail.com ${ }^{2} \mathrm{PhD}$ in Agronomy, Adjunct Professor of Biological Sciences Course, Universidade Estadual do Ceará. E-mail: eliseu.lucena@uece.br ${ }^{3} \mathrm{PhD}$ in Ecology, Associate Professor of Biological Sciences Course, Universidade Estadual do Ceará. E-mail: oriel.herrera@uece.br ${ }^{4}$ Master in Food Science and Technology, Analyst at the Laboratory of Post-Harvest Physiology and Technology, Embrapa Agroindústria Tropical. E-mail: marcia.silveira@embrapa.br

${ }^{5}$ Master in Food Science and Technology, Professor of Food Technology Course, Faculdade de Tecnologia Informática. E-mail: antenor jr@hotmail.com
} 


\section{Introduction}

The fruit farming is present in all Brazilian states and as an economic activity employs around 5.6 million people, directly and indirectly. As a result, Brazil ranks as the third largest producer in the world, harvesting around 43 million tons of fresh fruit per year, $53 \%$ of which is destined for the fresh fruit market and $47 \%$ for processed fruit, but only $3 \%$ of the national harvest is exported in natura and $26 \%$ is exported processed, which shows the strong internal consumption (ANUÁRIO BRASILEIRO DE FRUTICULTURA, 2016).

On the coast of Ceará, the native fruits occupy a prominent place in the diverse ecosystems and, in general, their fruits are commercialized in the regional market with great popular acceptance, playing an important role in the population and native animal nutrition. One of these fruits is the manipuçá (Mouriri cearensis Huber). Also known as puçá, it belongs to the Melastomataceae family, which vegetates in Restinga environment and is native to Ceará. The fruits of the manipuçá are very appreciated, when consumed in natura, by the communities of the coast of Ceará (LUCENA et al., 2011b).

In the dynamic market economy, the development of new products is an essential factor for the survival of companies, especially those of food, which often need to release new products in order to remain ahead of an increasingly competitive market. Consumers today have raised their expectations for new products and have reduced their loyalty to traditional brands, which makes the food market even more competitive (DAMIANI et al., 2012). In this sense, the manipuçá is a good choice of raw material for the production of jelly, since the jellies constitute an important alternative for the use, processing and consumption of fruits (BASU et al., 2013).

The jelly of the manipuçá can be a viable alternative to complement the school meal of students of public schools, because according to Bezerra and Arimatea (2009), the soup, although it is a meal that the students can like, is a food served repeatedly, which the students dislike. This is due to the fact that the monetary value transferred to schools is too low for a diversified diet.

Given the above, this research aimed to make the physical, chemical, microbiological and sensorial characterization of manipuçá jelly as an alternative to school meal of elementary school of Fortaleza-CE municipal public schools.

\section{Materials and methods}

The study was conducted at the Vegetable Ecophysiology Laboratory-ECOFISIO, of the State University of Ceará-UECE, at the Laboratory of PostHarvest Physiology and Technology of Embrapa Tropical Agroindustry and at the Experimental Nucleus in Science and Technology of Regional Food of the UECE, all in
Fortaleza-CE, from February 2015 to July 2016.

The research project was approved by the UECE Research Ethics Committee (CAAE n. 52661815.4.0000.5534 and Purpose n. 1.532.819).

Voucher of manipuçá (Mouriri cearensis Huber) (57407) is deposited in the Prisco Bezerra Herbarium, at the Federal University of Ceará-UFC, in Fortaleza-CE.

The fruits, characterized according to the peel color in stage 4 (ripe $-90 \%$ orange and $10 \%$ light green) and 5 (senescent $-100 \%$ orange) of maturation (GONÇALVES et al., 2017), were harvested manually and randomly from 10 matrices previously chosen in the São Gonçalo Botanical Garden, in São Gonçalo do Amarante-CE, located between the coordinates $3^{\circ} 36^{\prime} 26^{\prime \prime}$ south latitude and $38^{\circ} 58^{\prime} 06^{\prime \prime}$ west longitude, consisting of Restinga. Adult, healthy and uniform maturing plants were selected. A flow chart of the jelly processing can be seen in Figure 1.
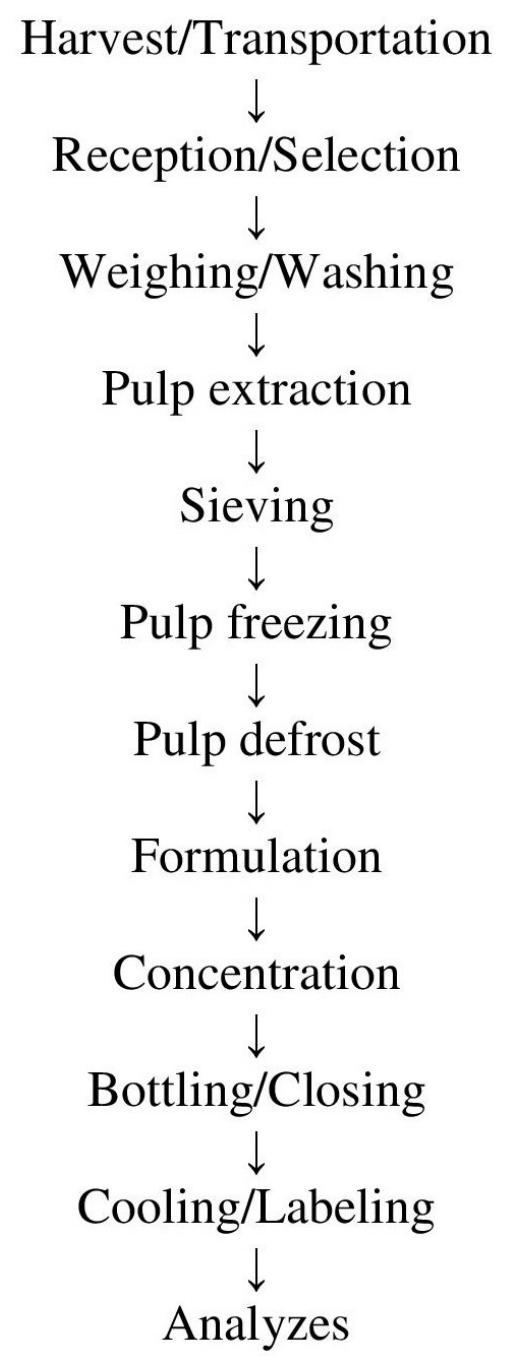

Figure 1 - Processing flowchart for manipuçá jelly (Mouriri cearensis Huber). 
The fruits were transported to ECOFISIO, where they were received, manually selected, weighed and washed in chlorinated water at $20 \mathrm{ppm}$. The pulp extraction was carried out in an industrial blender for five minutes, using the entire fruit, that is, with peel, pulp and seed. The amount of water used for extraction was twice the mass of the fruits. $50 \%$ of the fruits were harvested at stage 4 and $50 \%$ at stage 5 . The sieving was then done in stainless steel sieves; the pulp was packed in low-density polyethylene bags and frozen in a freezer at $-18^{\circ} \mathrm{C}$ for later use.

For the preparation of the jelly formulations, the pulp was defrosted and sugar, pectin, citric acid, sodium benzoate and water were added. The amount of additives and the concentration time varied according to the proportion of water and pulp (Table 1) in the five formulations (treatments) tested (4:1-Formulation $1-\mathrm{F}_{1} ; 4: 2-$ Formulation $2-\mathrm{F}_{2} ; 4: 3-$ Formulation $3-\mathrm{F}_{3}$; 4:4-Formulation $4-\mathrm{F}_{4}$; and 4:5-Formulation $5-\mathrm{F}_{5}$ ).
The jellies were packed in polypropylene jars, sealed and identified. The physical, chemical, microbiological and sensory analyzes of the jellies were then carried out.

The physical and chemical analyses realized were: total soluble solids (TSS), according to the methodology recommended by AOAC (2005); total titratable acidity (TTA), by titration, according to Brasil (2005a); pH, according to AOAC (2005); TSS/TTA relation (SAR), obtained by the quotient between the two variables; $C$ Vitamin (CV), obtained by titrimetry, according to the methodology of Strohecker and Henning (1967); total soluble sugars (TSSu) by the antrona method, according to the methodology described by Yemn and Willis (1954); reducing sugars (RS), determined by the DNS method (dinitrosalicyclic), according to the methodology described by Miller (1959); non-reducing sugars (NRS), which were obtained by the difference between the TSSu and the RS, according to Lucena et al. (2011a).

Table 1 - Quantitative of the components in the formulations of the manipuça jelly (Mouriri cearensis Huber).

\begin{tabular}{cccccc}
\hline \multirow{2}{*}{ Components } & \multicolumn{5}{c}{ Formulations } \\
\cline { 2 - 6 } & $\mathrm{F}_{1}$ & $\mathrm{~F}_{2}$ & $\mathrm{~F}_{3}$ & $\mathrm{~F}_{4}$ & $\mathrm{~F}_{5}$ \\
\hline Sugar $(\mathrm{g})$ & 1660 & 2000 & 2340 & 2660 & 3000 \\
Pulp $(\mathrm{mL})$ & 500 & 1000 & 1500 & 2000 & 2500 \\
Water $(\mathrm{mL})$ & 2000 & 2000 & 2000 & 2000 & 2000 \\
Citric acid $(\mathrm{g})$ & 20 & 20 & 20 & 20 & 20 \\
Pectin $(\mathrm{g})$ & 20 & 20 & 20 & 20 & 20 \\
Sodium benzoate $(\mathrm{g})$ & 4 & 4 & 4 & 4 & 4 \\
\hline
\end{tabular}

The presumptive test for coliforms was also necessary to carry out, that is coliforms at $35^{\circ} \mathrm{C}$ (SILVA et al., 2007), in order to guarantee the safety of the tasters in the sensorial analysis.

The sensory evaluation of the jellies was carried out with 50 untrained elementary students from the José Valdevino de Carvalho Municipal School, located at Rua Guará, S/N, Itaoca Neighborhood, Fortaleza-CE, Municipal Education Department, District IV. The tasters assessed aroma, color, appearance, flavor and texture using the nine-point structured hedonic scale, the extremes being "extremely enjoyed" (9) and "extremely disagreeable" (1). For the purchase intention, we used the structured scale of five points, whose extremes were: "I would certainly buy it" (5) and "I certainly would not buy it" (1) (IAL, 2008).

The experimental design was completely randomized, with five treatments (formulations) and four or fifty repetitions, depending on the analysis (physical-chemical or sensorial, respectively). The results were submitted to the analysis of variance observing the significance by the $\mathrm{F}$ test and when significant, the Tukey test was carried out at the $5 \%$ probability level, using the Assistat 7.7 beta statistic program.

\section{Results and discussion}

The total soluble solids (TSS) in the manipuçá jelly increased with the increase of the formulation concentration $(\mathrm{F})$, increasing from $72^{\circ} \mathrm{Brix}$ in formulation $1\left(\mathrm{~F}_{1}\right)$ to $85.12^{\circ}$ Brix in formulation $5\left(\mathrm{~F}_{5}\right)$ (Table 2). Although the added sugar mass was calculated in order for all formulations to have proportionally the same amount of sugar $(40 \%)$, the concentration time increased with the increase of the formulation concentration, since it took more time to evaporate the water and, consequently, promoted a higher concentration of TSS.

The values of the TSS in the manipuçá jelly in this study are superior to the value in murici jelly (Byrsonima sp.) stored at room temperature with $64.8^{\circ}$ Brix (MONTEIRO; PIRES, 2016), in extra graviola jelly (Annona muricata L.) with pepper (Capsicum baccatum L.), with $65^{\circ}$ Brix (TELES et al., 2017), in mixed jelly of pineapple peel (Ananas comosus (L.) Merr.) with peach pulp (Prunus persica (L.) Batsch), with $65^{\circ}$ Brix (VIEIRA et al., 2017), in conventional umbu-cajá jelly (Spondias bahiensis P. Carvalho, Van den Berg \& M. Machado) Suprema genotype, with $65.10^{\circ}$ Brix and in the Preciosa genotype, with $65^{\circ}$ Brix (VIANA et al., 2015). 
The titratable total acidity (TTA) in the manipuçá jelly was decreasing with the increase of the formulation concentration, decreasing from $0.95 \%$ of citric acid in $\mathrm{F}_{1}$ to $0.54 \%$ of citric acid in $\mathrm{F}_{5}$ (Table 2 ). This behavior occurred because the amount of pulp added in the formulations was increasing, while the citric acid was constant, therefore, the higher dilution caused the reduction of the acidity.

The highest TTA value in the jelly of this research was higher than those found in murici jelly, with $0.50 \%$ of citric acid (MONTEIRO; PIRES, 2016), in mixed pineapple peel with peach pulp jelly, with $0.25 \%$ of citric acid (VIEIRA et al., 2017), in the umbu-cajá Suprema genotype jelly with $0.73 \%$ of citric acid and in the Preciosa genotype, with $0.66 \%$ of citric acid (VIANA et al., 2015). On the other hand, it is inferior to that found in extra graviola jelly with pepper, with $1.65 \%$ of citric acid (TELES et al., 2017) and cagaita jelly (Eugenia dysenterica DC.), with $1.28 \%$ of citric acid (SANTOS et al., 2012).

The $\mathrm{pH}$ in the manipuçá jelly increased with the increase in the formulation concentration, increasing from 4.09 in $\mathrm{F}_{1}$ to 4.30 in $\mathrm{F}_{5}$ (Table 2). This is probably due to the amount of pulp added in the formulations have been increasing while the citric acid was constant, therefore, the higher dilution caused the acidity reduction and consequently the $\mathrm{pH}$ rise.

The $\mathrm{pH}$ values obtained in the manipuçá jelly of this research were higher than those found in conventional jelly of umbu-cajá Suprema genotype, with $\mathrm{pH}$ of 2.36 and in the Preciosa genotype, with $\mathrm{pH}$ of 2.42 (VIANA et al., 2015), in murici jelly stored at room temperature, with $\mathrm{pH}$ of 3.43 (MONTEIRO; PIRES, 2016), in extra graviola jelly with pepper, with $\mathrm{pH}$ of 3.69 (TELES et al., 2017) and mixed pineapple and peach pulp jelly, with $\mathrm{pH} 3.50$ (VIEIRA et al., 2017).

The TSS/TTA ratio (SAR) in the manipuça jelly was increasing with the increase in formulation concentration, increasing from 75.22 in $\mathrm{F}_{1}$ to 156.20 in $\mathrm{F}_{5}$ (Table 2). The TSS/TTA ratio is more representative than the isolated measurement of sugars or acidity, since this ratio, besides giving a good idea of the balance between these two components, indicates the degree of sweetness.

The highest value above the SAR in the manipuçá jelly was higher than that found in murici jelly stored at room temperature with SAR of 129.60 (MONTEIRO; PIRES, 2016), in a conventional umbu-cajá jelly Preciosa genotype with SAR of 98.48 in the Suprema genotype, with SAR of 89.17 (VIANA et al., 2015) and in extra graviola jelly with pepper, with SAR of 39.39 (TELES et al., 2017). On the other hand, it is inferior to that found in mixed pineapple peel with peach pulp jelly, with SAR of 260.00 (VIEIRA et al., 2017).

The C Vitamin (CV) in the manipuçá jelly was increasing with the increasing formulation concentration, increasing from $10.72 \mathrm{mg}$ of ascorbic acid/100 $\mathrm{g}$ of jelly in $\mathrm{F}_{1}$ to $14.19 \mathrm{mg}$ ascorbic acid/100 $\mathrm{g}$ of jelly in $\mathrm{F}_{5}$ (Table 2). Although there is no recommended value for $\mathrm{CV}$ for jellies in Brazilian legislation, the values obtained in this research partially meet the need for daily recommended intake of CV for adults, which is $45 \mathrm{mg}$ according to RDC n. 269 (BRASIL, 2005b) because they contain this amount in more than $100 \mathrm{~g}$ of jelly. Therefore, if we consider the lowest and the highest value of CV found in this study, $608.10 \mathrm{~g}$ of $\mathrm{F}_{2}$ and $317.12 \mathrm{~g}$ of $\mathrm{F}_{5}$ of manipuçá jelly must be consumed to meet this need.

The results of CV in the manipuçá jelly observed in this study were significantly lower than that found by Assis et al. (2007), in cashew jelly (Anacardium occidentale L.) at time zero, which was $184.01 \mathrm{mg}$ of ascorbic acid/100 $\mathrm{g}$ of the sample and in cagaita jelly, in which Santos et al. (2012) obtained $31.22 \mathrm{mg}$ of ascorbic acid/100 $\mathrm{g}$ of the sample. On the other hand, they are superior to that found in extra graviola jelly with pepper, which was $0.889 \mathrm{mg}$ of ascorbic acid/100 $\mathrm{g}$ of the sample (TELES et al., 2017).

The total soluble sugars (TSSu) in the manipuçá jelly were increasing with the increase in formulation concentration, increasing from $63.97 \%$ in $\mathrm{F}_{1}$ to $79.73 \%$ in $\mathrm{F}_{5}$ (Table 2). According to the increase of TSSu in the formulations, we found that although the proportional amount of sugar added was the same, the added pulp volume was increasing, thus, it took longer to evaporate the water and consequently provided a concentration of TSSu.

The lowest value of TSSu (63.97\%) in the manipuçá jelly presented in this study was similar to the results found by Souza et al. (2015) in jellies obtained from blackberry fruits harvested at 3 different harvest stages, which were $60.08 \%$ with $100 \%$ red fruits, $61.84 \%$ with $50 \%$ red fruits and $50 \%$ black, $59.54 \%$ with $100 \%$ black fruits. On the other hand, it was superior to that obtained in mixed pineapple peel with peach pulp jelly, with 44.56\% (VIEIRA et al., 2017), in conventional umbu-cajá jelly Preciosa genotype, with 56.28 and in the Suprema genotype, with $57.05 \%$ (VIANA et al., 2015).

The reducing sugars (RS) in the manipuça jelly decreased from $\mathrm{F}_{1}(51.49 \%)$ to $\mathrm{F}_{2}(44.53 \%)$ and then increased up to $\mathrm{F}_{5}(66.98 \%)$ (Table 2$)$. The increase of $\mathrm{RS}$ in the formulations was expected because the longer the concentration time is, the greater the inversion will be, the hydrolysis of sucrose into glucose and fructose.

The RS values in the manipuçá jelly verified in this research are superior to those found in jellies obtained from blackberry fruits harvested in 3 different stages of harvest, that were $36.09 \%$ with $100 \%$ red fruits, $37.74 \%$ with $50 \%$ red fruits and $50 \%$ black, $34.94 \%$ with $100 \%$ black fruits (SOUZA et al., 2015) and mixed pineapple peel with peach pulp jelly, with $18.90 \%$ (VIEIRA et al., 2017).

The non-reducing sugars (NRS) in the manipuçá jelly increased from $F_{1}(12.47 \%)$ to $F_{4}(32.98 \%)$ and then decreased to $\mathrm{F}_{5}(12.74 \%)$ (Table 2). 
Table 2 - Physical and chemical characteristics of manipuçá jellies (Mouriri cearensis Huber).

\begin{tabular}{ccrrrr}
\hline \multirow{2}{*}{ Specifications } & \multicolumn{5}{c}{ Formulations } \\
\cline { 2 - 6 } & $\mathrm{F}_{1}$ & \multicolumn{1}{c}{$\mathrm{F}_{2}$} & \multicolumn{1}{c}{$\mathrm{F}_{3}$} & \multicolumn{1}{c}{$\mathrm{F}_{4}$} & \multicolumn{1}{c}{$\mathrm{F}_{5}$} \\
\hline TSS ( ${ }^{\circ}$ Brix) & $72.00 \mathrm{e}$ & $73.25 \mathrm{~d}$ & $76.12 \mathrm{c}$ & $81.00 \mathrm{~b}$ & $85.12 \mathrm{a}$ \\
TTA (\%) & $0.95 \mathrm{a}$ & $0.71 \mathrm{~b}$ & $0.62 \mathrm{c}$ & $0.56 \mathrm{~d}$ & $0.54 \mathrm{~d}$ \\
pH & $4.09 \mathrm{~d}$ & $4.17 \mathrm{c}$ & $4.21 \mathrm{~b}$ & $4.28 \mathrm{a}$ & $4.30 \mathrm{a}$ \\
SAR & $75.22 \mathrm{e}$ & $102.45 \mathrm{~d}$ & $122.91 \mathrm{c}$ & $143.54 \mathrm{~b}$ & $156.20 \mathrm{a}$ \\
CV (mg/100 g) & $10.72 \mathrm{ab}$ & $7.40 \mathrm{~b}$ & $13.06 \mathrm{a}$ & $14.16 \mathrm{a}$ & $14.19 \mathrm{a}$ \\
TSSu (\%) & $63.97 \mathrm{~d}$ & $66.69 \mathrm{c}$ & $73.54 \mathrm{~b}$ & $79.06 \mathrm{a}$ & $79.73 \mathrm{a}$ \\
RS (\%) & $51.49 \mathrm{~b}$ & $44.53 \mathrm{c}$ & $45.96 \mathrm{c}$ & $46.07 \mathrm{c}$ & $66.98 \mathrm{a}$ \\
NRS (\%) & $12.47 \mathrm{~d}$ & $22.15 \mathrm{c}$ & $27.58 \mathrm{~b}$ & $32.98 \mathrm{a}$ & $12.74 \mathrm{~d}$ \\
\hline
\end{tabular}

*Averages followed by the same letter in line do not differ from each other by Tukey test at $5 \%$ probability of error.

The NRS results of $F_{1}$ and $F_{5}$ in the manipuçá jelly of this research were lower than that found in jellies obtained from blackberry fruits harvested at 3 different harvest stages, which were $23.99 \%$ with $100 \%$ red fruits, $24.10 \%$ with $50 \%$ red and $50 \%$ black fruits, $24.60 \%$ with $100 \%$ black fruits (SOUZA et al., 2015) and mixed pineapple peel with peach pulp jelly, with $25.66 \%$ (VIEIRA et al., 2017). Only the $\mathrm{F}_{4}$ was superior to the results obtained by the aforementioned authors.

For all samples of the presumptive test for coliforms, the results were negative for coliforms at $35^{\circ} \mathrm{C}$. Although the RDC n. 12 (BRASIL, 2001) does not mention targets to be reached in the research of coliforms for jelly, they may indicate deficiencies in the heat treatment (HAJDENWURCEL, 1998). The results suggest that there were good procedures in the processing of jellies, such as adequate sanitation of fruits and equipment used, as well as the effectiveness of the conservation methods used.

In the sensory acceptance test (Figure 2) for aroma, color, appearance, taste and texture, the $\mathrm{F}_{5}$ was significantly higher than $\mathrm{F}_{2}, \mathrm{~F}_{3}$ and $\mathrm{F}_{4}$, while $\mathrm{F}_{5}$ did not differ significantly from $\mathrm{F}_{1}$. Only for the intention of purchase test, there was a significant superiority of $\mathrm{F}_{5}$ in relation to the other formulations $\left(\mathrm{F}_{1}, \mathrm{~F}_{2}, \mathrm{~F}_{3}\right.$ and $\left.\mathrm{F}_{4}\right)$.

According to Assis et al. (2007), studying three formulations of cashew jellies with clarified juice concentrations of 20,15 and $10^{\circ}$ Brix, we found that there is a difference in flavor among the formulations tested, with $10^{\circ}$ Brix being the most preferred followed by $15^{\circ}$ Brix and the less preferred with $20^{\circ} \mathrm{Brix}$. These results are contrary to those of this research with manipuçá jelly, in which the formulation that presented the best sensory results was the one with the highest TSS content $\left(\mathrm{F}_{5}-85\right.$, $12^{\circ}$ Brix).

On the other hand, Viana et al. (2015) evaluated the intention to buy of four formulations of conventional and dietary umbu-cajá jellies, they verified that $70 \%$ of the consumers indicated that they would buy the conventional jelly formulation elaborated with the Suprema genotype, that is, the formulation of jelly with higher TSS $(61.10 \%)$ and $\mathrm{TSSu}(57.05 \%)$ was preferred among tasters, such as the F5 in this study with jelly, with levels of TSS (85.12\%),
TSSu (79.73\%) and RS (66.98\%) higher than the other formulations $\left(\mathrm{F}_{1}, \mathrm{~F}_{2}, \mathrm{~F}_{3}\right.$ and $\left.\mathrm{F}_{4}\right)$.

Santos et al. (2012), investigating four formulations of cagaita jelly through the use of two types of pulp (filtered or unfiltered) and two proportions of pulp:sucrose:pectin (50:50:0.2 and 60:40:0.1), they found that there was no significant difference between the jelly formulations for flavor, color, aroma, texture and overall impression attributes ( $p>0.05)$, although in this study with manipuçá jellies, significant differences were obtained for the aroma, color, appearance, taste, texture and purchase intention attributes.

Vieira et al. (2017), studying the acceptability of mixed pineapple peel with peach pulp jelly, found that all the attributes evaluated in the acceptability test obtained average scores between 8 (I liked it very much) and 9 (I liked it a lot), indicating high acceptance of the product, which was corroborated by the alleged intention to buy, which was $91 \%$. These results were similar to those of this study for the $\mathrm{F}_{5}$ of manipuçá jelly, because for aroma, color, flavor and texture, the acceptability was also between 8 (I liked it very much) and 9 (I liked it a lot), which was corroborated by the intention to buy of 4.02 (I would probably buy it). 


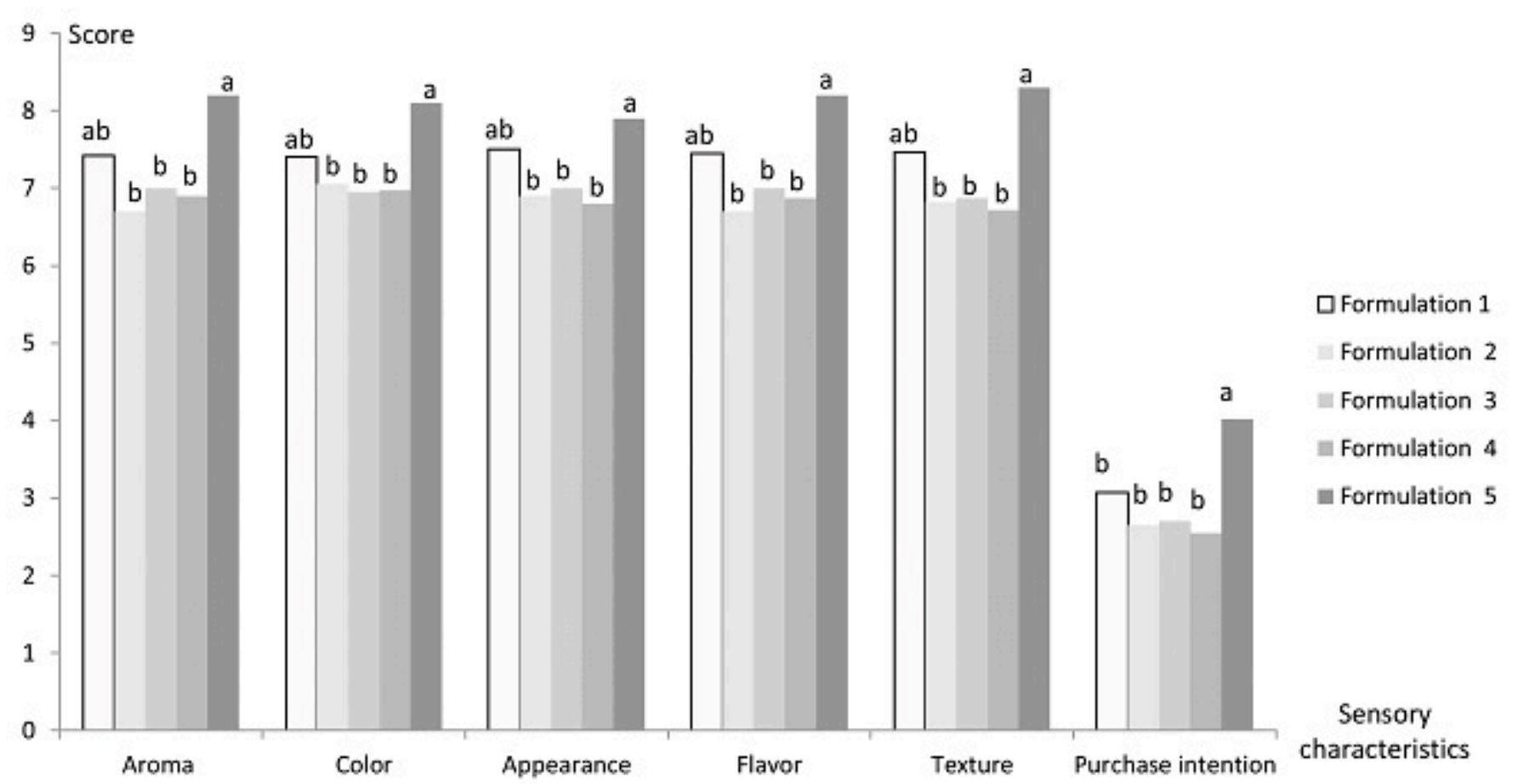

Figure 2 - Sensorial characteristics of manipuçá jellies (Mouriri cearensis Huber).

Averages followed by the same letter in the same sensorial characteristic do not differ from each other by Tukey test at $5 \%$ probability of error.

\section{Conclusions}

The total soluble solids (TSS), the pH, TSS/ TTA ratio (SAR), $\mathrm{C}$ vitamin ( $\mathrm{CV}$ ), total soluble sugars (TSSu) increased with the increase in the concentration of manipuçá jelly formulation (F), however, the titratable total acidity (TTA) was decreasing. On the other hand, reducing sugars (RS) and non-reducing sugars (NRS) showed fluctuations with the increase in the concentration of the manipuçá jelly formulation, with a tendency to increase for both variables.

The formulation 5 (F5) is the sweetest and least acidic; however, the formulation $\mathrm{F}_{1}$ is the least sweet and more acidic, of the tested formulations.

The processing of the jelly was done in good hygienic conditions, since no coliforms were found in the presumptive test.

In general, the formulation $5\left(\mathrm{~F}_{5}\right)$ was more widely accepted among students, therefore, this is the ideal formulation to be used as an alternative in school meals for elementary school students in Fortaleza-CE municipal schools.

\section{Acknowledgements}

We thank to Embrapa Tropical Agroindustry and to the Experimental Nucleus in Science and Technology of Regional Foods for the technical support; to the Botanical Garden of São Gonçalo and the Municipal School José Valdevino de Carvalho for logistical support.

\section{References}

ANUÁRIO BRASILEIRO DE FRUTICULTURA 2016. Santa Cruz do Sul: Editora Gazeta, 2016. 88p.

AOAC - Association of Official Analytical Chemists. Official methods of analysis of AOAC International. $18^{\text {th }}$ ed. Gaithersburg: AOAC International, 2005. 1219p.

ASSIS, M.M.; MAIA, G.A.; FIGUEIREDO, E.A.T.; FIGUEIREDO, R.W.; MONTEIRO, J.C.S. Processamento e estabilidade da geleia de caju. Revista Ciência Agronômica, Fortaleza, v.38, n.1, p.46-51, 2007.

BASU, S.; SHIVHARE, U.S.; SINGH, T.V. Effect of substitution of stevioside and sucralose on rheological, spectral, color and microstructural characteristics of mango jam. Journal of Food Engineering, Oxford, v.114, n. 4, p. $465-476,2013$.

BEZERRA, B.; ARIMATEA, J. Alimentação e escola: significados e implicações curriculares da merenda escolar. Revista Brasileira de Educação, Rio de Janeiro, v.14, n.40, p.103-115, 2009.

BRASIL. Ministério da Saúde. Agência Nacional de Vigilância Sanitária. Métodos físico-químicos para análise de alimentos. 4. ed. Brasília: Ministério da Saúde, 2005a. 119p. 
BRASIL. Ministério da Saúde. Agência Nacional de Vigilância Sanitária. Resolução RDC n⿳0 269, de 22 de setembro de 2005. Regulamento técnico sobre a ingestão diária recomendada (IDR) de proteína, vitaminas e minerais. Brasília, 2005b. Disponível em: $\leq$ http://portal. anvisa.gov.br/documents/33916/394219/RDC 2692005. $\mathrm{pdf} / 2 \mathrm{e} 95553 \mathrm{c}-\mathrm{a} 482-45 \mathrm{c} 3-\mathrm{bdd} 1-\mathrm{f} 96162 \mathrm{~d} 607 \mathrm{b3}>$. Acesso em: 15 maio 2017.

BRASIL. Ministério da Saúde. Secretaria de Vigilância Sanitária. Resolução RDC nº 12, de 02 de janeiro de 2001. Regulamento técnico sobre os padrões microbiológicos para alimentos. Diário Oficial da República Federativa do Brasil, Brasília, n.7-E, 10 jan. 2001. p.45-53.

DAMIANI, C.; ASQUIERI, E.R.; LAGE, M.E.; OLIVEIRA, R.A.; SILVA, F.A.; PEREIRA, D.E.P.; VILAS BOAS, E.V.B. Study of the shelf-life of a mixed araça (Psidium guineensis $\mathrm{Sw}$.) and marolo (Annona crassiflora Mart.) jam. Ciência e Tecnologia de Alimentos, Campinas, v.32, n.2, p.334-343, 2012.

GONÇALVES, N.P.; LUCENA, E.M.P.; BONILLA, O.H.; SILVEIRA, M.R.S. Polyphenols and antioxidant activity of four fruits native to the coast of Ceara under different maturation stages. Revista Brasileira de Fruticultura, Jaboticabal, v.39, n.1, p.1-7, 2017.

HAJDENWURCEL, J.R. Atlas de microbiologia de alimentos. São Paulo: McGraw-Hill, 1998. v.1, 66p.

IAL - Instituto Adolfo Lutz. Métodos físico-químicos para análise de alimentos. 4. ed. São Paulo: IAL, 2008. 1020p.

LUCENA, E.M.P.; ASSIS, J.S.; ALVES, R.E.; ENÉAS FILHO, J. Comportamento dos carboidratos e amilases de mangas Tommy Atkins durante o desenvolvimento. Journal of the Interamerican Society for Tropical Horticulture, Fortaleza, v.54, p.109-112, 2011a.

LUCENA, E.M.P.; MAJOR. I.; BONILLA, O.H. Frutas do litoral cearense. Fortaleza: EdUECE, 2011b. 112p.

MILLER, G.L. Use of dinitrosalicylic acid reagent for determination of reducing sugars. Analytical Chemistry, Washington, v.31, n.3, p.426-428, 1959.
MONTEIRO, D.C.B.; PIRES, C.R.F. Avaliação da estabilidade físico-química de geleias de murici armazenadas sob diferentes condições de temperatura e luminosidade. Revista Desafios, Palmas, v.3, p.87-98, 2016. Número especial.

SANTOS, P.R.G.; CARDOSO, L.M.; BEDETTI, S.F.; HAMACEK F.R.; MOREIRA, A.V.B.; MARTINO, H.S.D.; PINHEIRO-SANT'ANA, H.M. Geleia de cagaita (Eugenia dysenterica DC.): desenvolvimento, caracterização microbiológica, sensorial, química e estudo da estabilidade. Revista Instituto Adolfo Lutz, São Paulo, v.71, n.2, p.281-290, 2012.

SILVA, N.; JUNQUEIRA, V.C.A.; SILVEIRA, N.F.A.; TANIWAKI, M.H.; SANTOS, R.F.S.; GOMES, R.A.R. Manual de métodos de análise microbiológica de alimentos. 3. ed. São Paulo: Varela, 2007. 536p.

SOUZA, A.V.; RODRIGUES, R.J.; GOMES, E.P.; GOMES, G.P.; VIEITES, R.L. Caracterização bromatológica de frutos e geleias de amora-preta. Revista Brasileira de Fruticultura, Jaboticabal, v.37, n.1, p.1319, 2015.

STROHECKER, R.; HENNING, H.M. Analisis de vitaminas: métodos comprobados. Madrid: Paz Montalvo, 1967. 428p.

TELES, A.C.M.; PINTO, E.G.; SANTOS, J.R.; OLIVEIRA, C.F.D.; SOARES, D.S.B. Desenvolvimento e caracterização físico-química de geleia comum e extra de graviola com pimenta. Revista de Agricultura Neotropical, Cassilândia, v.4, n.1, p.72-77, 2017.

VIANA, E.S.; MAMEDE, M.E.O.; REIS, R.C.; CARVALHO, L.D.; FONSECA, M.D. Desenvolvimento de geleia de umbu-cajá convencional e dietética. Revista Brasileira de Fruticultura, Jaboticabal, v.37, n.3, p.708717, 2015.

VIEIRA, E.C.S.; SILVA, E.P.;AMORIM, C.C.M.; SOUSA, G.M.; BECKER, F.S.; DAMIANI, C. Aceitabilidade e características físico-químicas de geleia mista de casca de abacaxi e polpa de pêssego. Científica, Jaboticabal, v.45, n.2, p.115-122, 2017.

YEMN, E.W.; WILLIS, A.J. The estimation of carbohydrate in plant extracts by anthrone. The Biochemical Journal, London, v.57, n.3, p.508-514, 1954. 